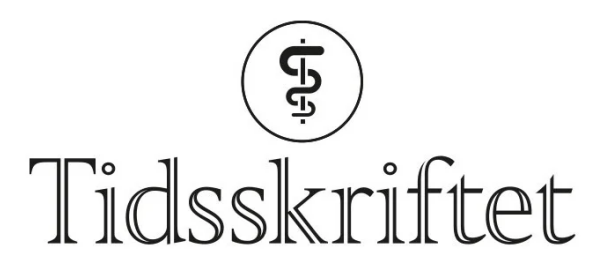

DEN NORSKE LEGEFORENING

\title{
Seksuelle konflikter mellom mann og kvinne
}

\author{
ANMELDELSER
}

MORTEN ANDERSEN

Moelv Spesialistsenter

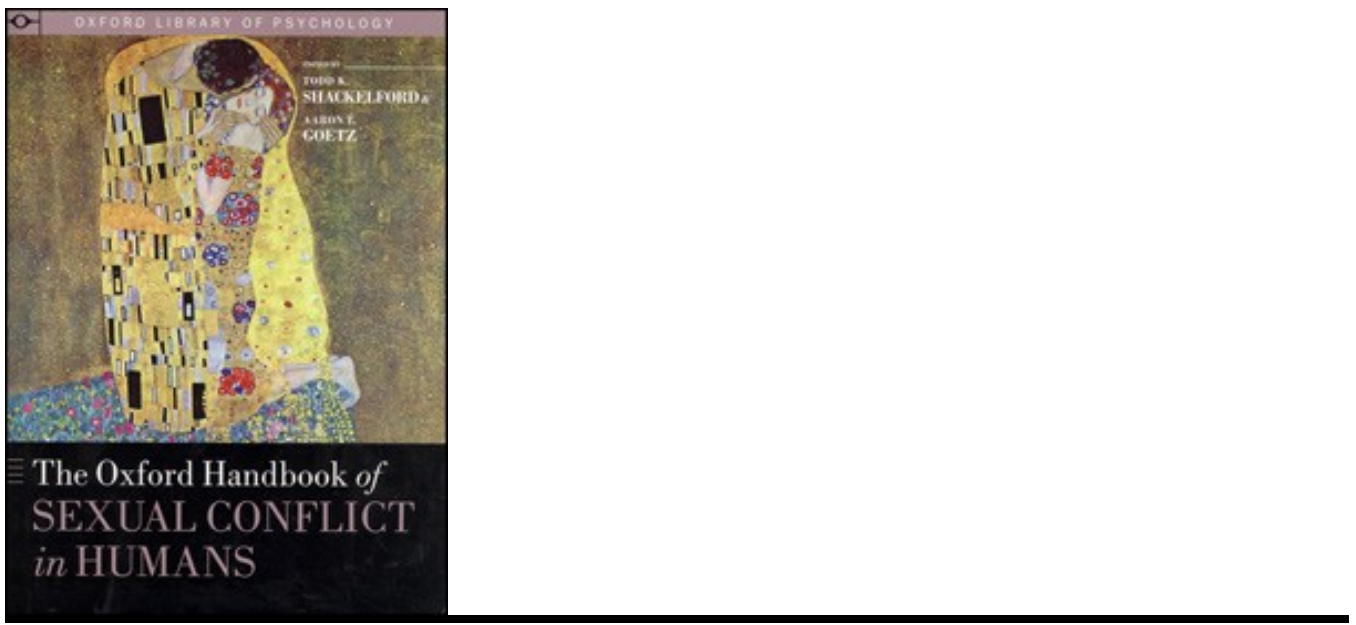

Shackelford, Todd K.

Goetz, Aaron T.

The Oxford handbook of sexual conflict in humans

349 s, tab, ill. Oxford: Oxford University Press, 2012. Pris GBP 85

ISBN 978-0-19-539670-6

Målet til Oxford Library of Psychology er å produsere høyaktuelle bøker innen psykologiens mange områder. Denne utgivelsen har en meget stor bredde, og forfatterne går dypt inn i de ulike seksuelle konfliktene mellom mann og kvinne. Boken vil derfor være aktuell for en rekke ulike fagområder innen psykologien, men også for andre kliniske fag som gynekologi, urologi og sexologi.

The Oxford handbook of sexual conflict in humans er den første boken i sitt slag som samler dagens viten, både teoretisk og empirisk, om seksuelle konflikter mellom mann og kvinne. Forfatterne har samarbeidet med 42 forskere innen psykologi og antropologi fra hele 
verden, og boken har derfor en imponerende referanseliste etter hvert kapittel. Det er fem hoveddeler, og det er oversiktlig og lett å finne ulike temaer av interesse. Boken kan derfor leses etter $\emptyset$ nsket tema og ikke nødvendigvis fra perm til perm. Flere illustrasjoner hadde vært ønskelig.

I introduksjonsdelen tar bidragsyterne for seg teorier og forskning innen seksuelle konflikter. Deretter følger egne deler som omhandler seksuelle konflikter før, under og etter samleie og eventuell befruktning. En rekke aspekter omtales grundig. Seksuell makt, sjalusi, partnervold og drap får egne omtaler. Menstruasjonssyklus, kvinnelig orgasme, sædinnhold og forholdet mellom ejakulat og kvinnens forplantningsorganer får en grundig gjennomgang. I disse kapitlene er det mye nyttig og ny viten som burde fenge interessen hos en rekke ulike fagpersoner.

En egen del omhandler seksuelle konflikter etter fødsel, både kvinnens og mannens spesifikke problemer, men også de problemene som oppstår i samspillet og samlivet mellom partnere etter barnefødsel. Til slutt diskuterer forfatterne hvordan seksuelle konflikter kan påvirkes av kulturelle, politiske og religiøse forhold.

Boken er absolutt leseverdig og meget innholdsrik og kan fungere som et oppslagsverk. Den er spekket med referanser og er preget av at innholdet er grundig validert. Det er en bok for dem som interesserer seg for seksuelle problemstillinger, og som ønsker forskningsbaserte fakta om dette spesielle emnet.

Publisert: 5. februar 2013. Tidsskr Nor Legeforen. DOI: 10.4045/tidsskr.12.1336

(C) Tidsskrift for Den norske legeforening 2023. Lastet ned fra tidsskriftet.no 26. april 2023. 